\title{
Sodium Thiosulfate
}

National Cancer Institute

\section{Source}

National Cancer Institute. Sodium Thiosulfate. NCI Thesaurus. Code C1230.

A water soluble salt and reducing agent that reacts with oxidizing agents. Although its exact mechanism of action is unknown, thiosulfate likely provides an exogenous source of sulfur, thereby hastening the detoxification of cyanide through the enzyme rhodanese (thiosulfate cyanide sulfurtransferase) which converts cyanide to the relatively nontoxic, excretable thiocyanate ion. In addition, this agent neutralizes the reactive alkylating species of nitrogen mustard, thereby decreasing skin toxicity related to nitrogen mustard extravasation. ( $\mathrm{NCl04)}$ 